
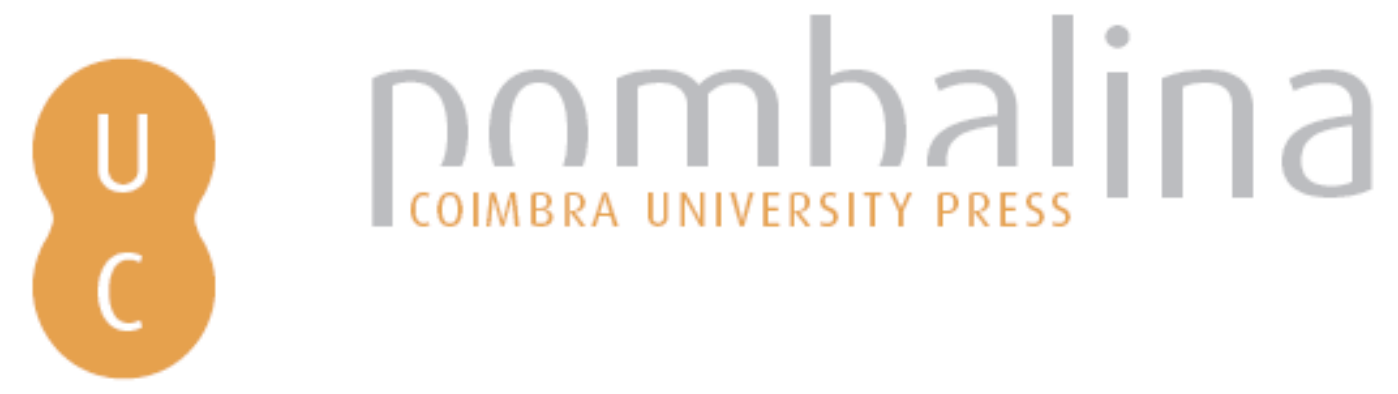

\title{
AmpFISTR $\circledast$ MiniFilerTM PCR Amplification kit: a powerful tool for genetic identification in criminal cases with low copy number samples
}

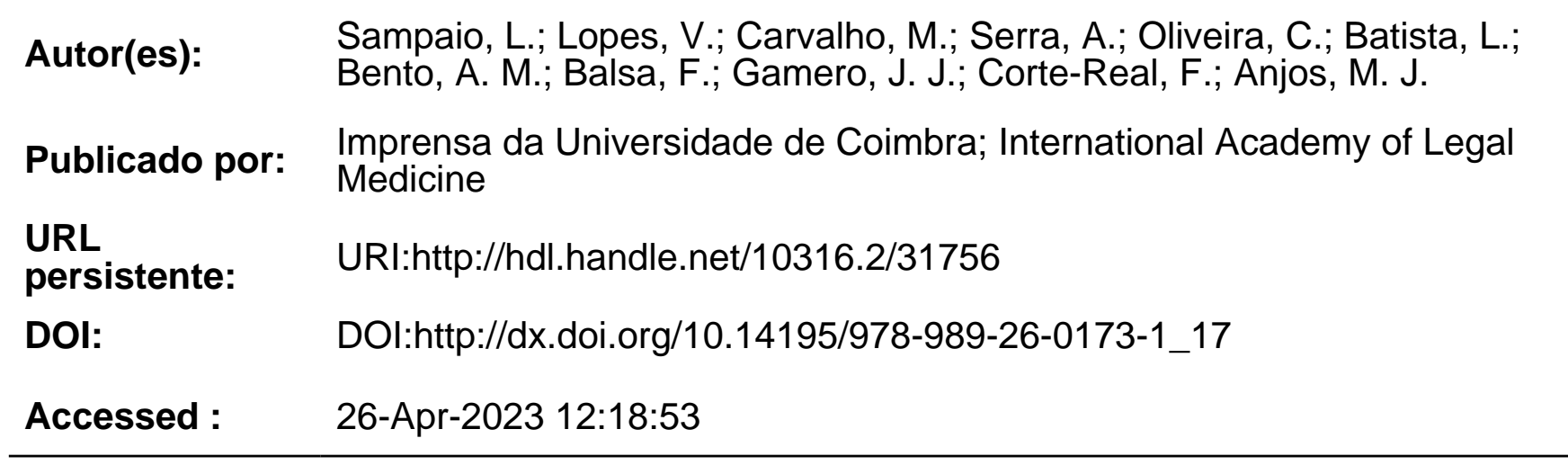

A navegação consulta e descarregamento dos títulos inseridos nas Bibliotecas Digitais UC Digitalis, UC Pombalina e UC Impactum, pressupõem a aceitação plena e sem reservas dos Termos e Condições de Uso destas Bibliotecas Digitais, disponíveis em https://digitalis.uc.pt/pt-pt/termos.

Conforme exposto nos referidos Termos e Condições de Uso, o descarregamento de títulos de acesso restrito requer uma licença válida de autorização devendo o utilizador aceder ao(s) documento(s) a partir de um endereço de IP da instituição detentora da supramencionada licença.

Ao utilizador é apenas permitido o descarregamento para uso pessoal, pelo que o emprego do(s) título(s) descarregado(s) para outro fim, designadamente comercial, carece de autorização do respetivo autor ou editor da obra.

Na medida em que todas as obras da UC Digitalis se encontram protegidas pelo Código do Direito de Autor e Direitos Conexos e demais legislação aplicável, toda a cópia, parcial ou total, deste documento, nos casos em que é legalmente admitida, deverá conter ou fazer-se acompanhar por este aviso.

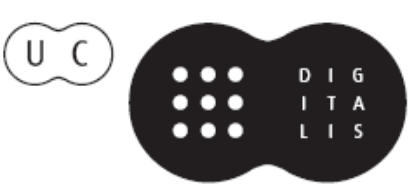




\section{Duarte Nuno Vieira Anthony Busuttil \\ Denis Cusack • Philip Beth}
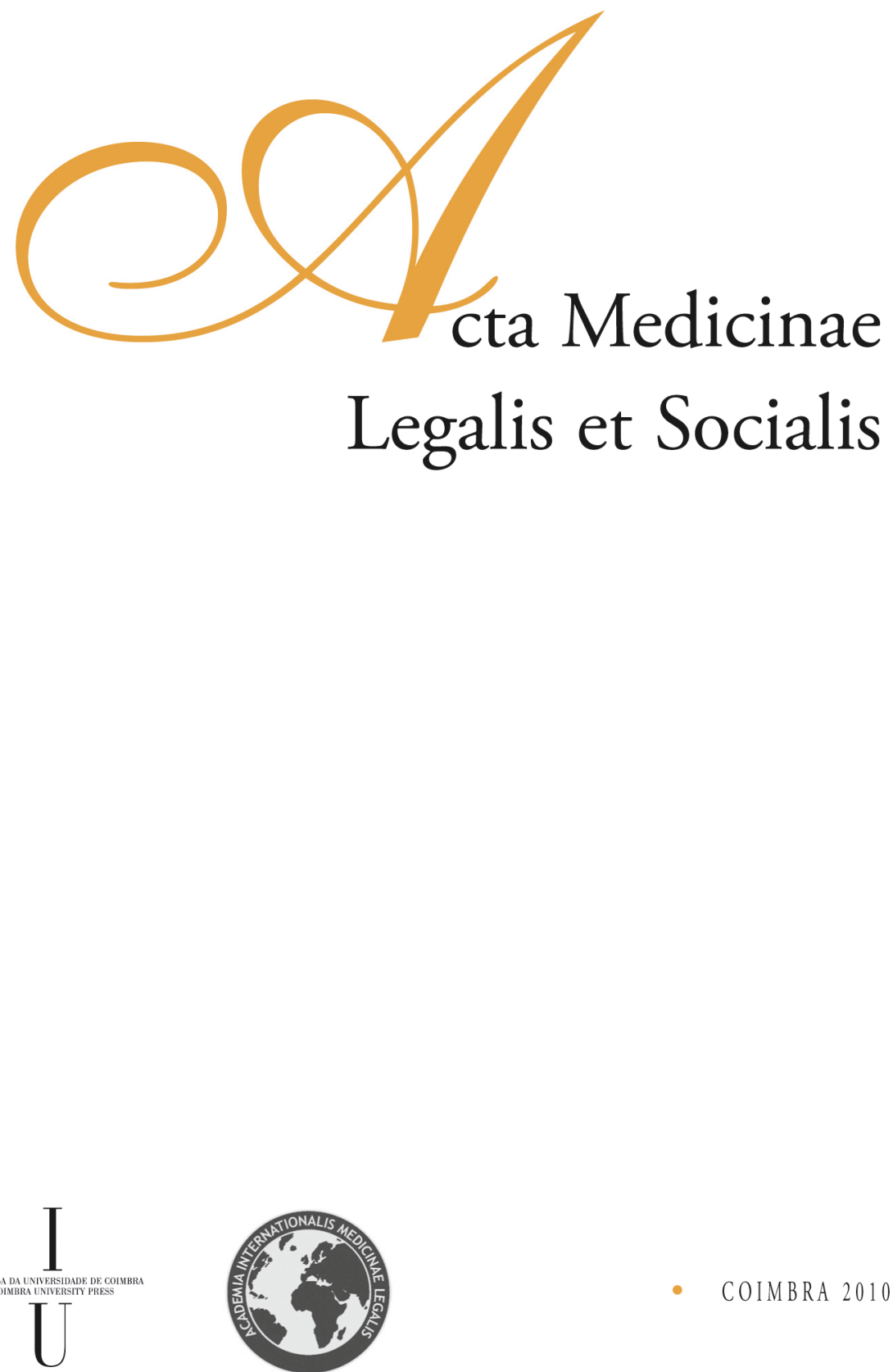
L. Sampaio ${ }^{1}$, V. Lopes $^{1}$, M. Carvalho ${ }^{1}$, A. Serra ${ }^{1}$, C. Oliveira ${ }^{1}$, L. Batista ${ }^{1}$, A. M. Bento ${ }^{1}$, F. Balsa ${ }^{1}$, J. J. Gamero ${ }^{2}$, F. Corte-Real ${ }^{3,4}$, M. J. Anjos ${ }^{1}$

${ }^{1}$ Genetic and Forensic Biology Department, Centre Branch of the National Institute of Legal Medicine, Portugal

${ }^{2}$ Department of Legal Medicine, Faculty of Medicine, University of Cadiz, Spain

${ }^{3}$ Centre Branch of the National Institute of Legal Medicine,

${ }^{4}$ Faculty of Medicine, University of Coimbra, Portugal

\title{
AMPFLSTR ${ }^{\circledR}$ MINIFILER ${ }^{\mathrm{TM}}$ PCR AMPLIFICATION KIT: A POWERFUL TOOL FOR GENETIC IDENTIFICATION IN CRIMINAL CASES WITH LOW COPY NUMBER SAMPLES
}

\begin{abstract}
The AmpFISTR ${ }^{\circledR}$ MiniFiler ${ }^{\mathrm{TM}}$ PCR Amplification kit (Applied Biosystems), a new available 8-mini-STR and the sex determining marker Amelogenin multiplex, includes the most common problematic loci (above $200 \mathrm{bp}$ ) of the AmpFlSTR ${ }^{\circledR}$ Identifiler $^{\mathrm{TM}}$ PCR Amplification kit: FGA, D21S11, D18S51, D13S317, D7S820, D16S539, CSF1PO and D2S1338. In several casework samples, with different DNA contents, results allowed to complete partial Identifiler ${ }^{\mathrm{TM}}$ profiles and additional information was achieved in Low Copy Number (LCN) samples, revealing that this miniSTR kit can improve identification of compromised samples [1].
\end{abstract}

\section{Introduction}

Multiplex STR typing of forensic samples is a powerful tool for genetic identification that allows quickly to achieve a high combined discrimination power with low DNA consumption (AmpFlSTR ${ }^{\circledR}$ Identifiler $^{\mathrm{TM}}$, Applied Biosystems, and PowerPlex ${ }^{\circledR} 16$ System, Promega, being the most common used PCR Amplification kits in our lab). If full profiles are obtained at the majority of high quality DNA samples, in degraded samples the higher molecular weight markers fail partial or completely their amplification. In order to minimize this problem several miniSTRs (with redesigned primers that generate reduced amplicon fragments) have been developed. This work is about a criminal case of a woman homicide (strangulated) followed by the suicide (hanged by a rope) of the principal suspect of the crime.

\section{Materials and Methods}

DNA extraction of LCN samples was made with Chelex 100 method [2] (nails and hand scrapings from both victim and aggressor, ropes - Figure 1 - used by the aggressor when trying to commit suicide) or commercial kits, namely DNA IQ ${ }^{\mathrm{TM}}$ System, Promega (three hairs collected in the mouth and in the right side of the victim's face). Samples were quantified with Quantifiler ${ }^{\circledR}$ Human DNA Quantification kit, 
Applied Biosystems, using an ABI Prism ${ }^{\circledR} 7000$, in accordance with the manufacturer's instructions. Amplification was made with the AmpFISTR ${ }^{\circledR}$ MiniFiler $^{\mathrm{TM}}$ and the AmpFISTR ${ }^{\circledR}$ Identifiler $^{\text {TM }}$ PCR Amplification kits, using an ABI Prism ${ }^{\circledR} 2700$, in accordance with the manufacturer's instructions. Samples were genotyped using an ABI Prism 3130 Analyser and the GeneMapper ID 3.2 software. In all laboratory procedures negative controls were tested, to despite contamination. To confirm results, all PCR amplifications were done twice.

\section{Results}

Just one hair had sufficient DNA quantity to be amplified with the AmpFISTR ${ }^{\circledR}$ MiniFiler ${ }^{\mathrm{TM}}$ Amplification kit, allowing to determine a female DNA profile, compatible with the victim's profile. In one of the analysed ropes, a male profile was obtained, using AmpFISTR ${ }^{\circledR}$ MiniFiler ${ }^{\mathrm{TM}}$ Amplification kit, compatible with the aggressor's profile. In nails and hand scrapings from both victim and aggressor mixed profiles were obtained with the AmpFISTR Identifiler ${ }^{\mathrm{TM}}$ PCR Amplification kit; sometimes these profiles were partial, with the need of being completed, through amplification with AmpFISTR ${ }^{\circledR}$ MiniFiler $^{\mathrm{TM}}$ Amplification kit. Negative controls were always clean. The minimum DNA quantity that allowed results with the MiniFiler ${ }^{\mathrm{TM}}$ was $15 \mathrm{pg} / \mu \mathrm{l}$.

\section{Discussion and Conclusions}

MiniFiler $^{\mathrm{TM}}$ is a commercial 9-plex miniature STR amplification kit, expected to revolutionize the way forensic scientists process casework samples by significantly increasing the ability to obtain information from DNA evidence, specially inhibited and/or degraded samples, that previously would have yielded limited or no genetic data. By combining innovative primer design, improved PCR amplification conditions and a properly mastermix, MiniFiler ${ }^{\mathrm{TM}}$ provides increased sensitivity, robust results in the presence of inhibitors and improved discrimination for casework samples. Working in conjunction with AmpFISTR ${ }^{\circledR}$ kits, MiniFiler ${ }^{\mathrm{TM}}$ can recover more complete DNA from challenging samples enabling more crime and missing person cases to be resolved. MiniFiler ${ }^{\mathrm{TM}}$ PCR Amplification kit has been demonstrated to yield the greatest amount of information from samples that have previously produced partial profiles or no profile at all using other existing commercially available autosomic amplification kits. In the presence of PCR inhibitors, MiniFiler ${ }^{\mathrm{TM}}$ outperforms other kits with regard to genetic information recovery. The use of a dual-amplification strategy (MiniFiler ${ }^{\text {TM }}$ and Identifiler ${ }^{\mathrm{TM}}$ ) is an adequate strategy to deal with compromised samples, allowing achieving information from the most common database autosomic markers, without the need of further population studies. In compromised samples, the largest molecular weight loci of Identifiler ${ }^{\mathrm{TM}}$, including FGA, D21S11, D18S51, D13S317, D7S820, D16S539, CSF1PO and D2S1338 most often fail to amplify. MiniFiler ${ }^{\mathrm{TM}}$ is a very useful kit in these situations (Figure 2), allowing to complete partial Identifiler ${ }^{\text {TM }}$ profiles and to achieve additional information in LCN samples. Important advantages 
of this new kit are also the possibility to verify the presence of false homozygotes and artefact peaks defined through Identifiler ${ }^{\mathrm{TM}}$. MiniFiler ${ }^{\mathrm{TM}}$ reduces stochastic effects produced in LCN samples amplifications.

\section{References}

www.minifiler.appliedbiosystems.com.

WALSH PS, METZGER DA, HIGUCHI R, Chelex 100 as a medium for simple extraction of DNA for PCR-based typing from forensic material, Biotechniques 10, 4, 506-513, 1991.

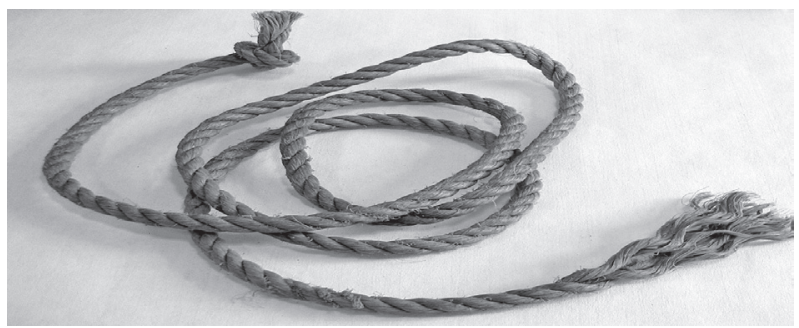

Figure 1 - One of analysed ropes.

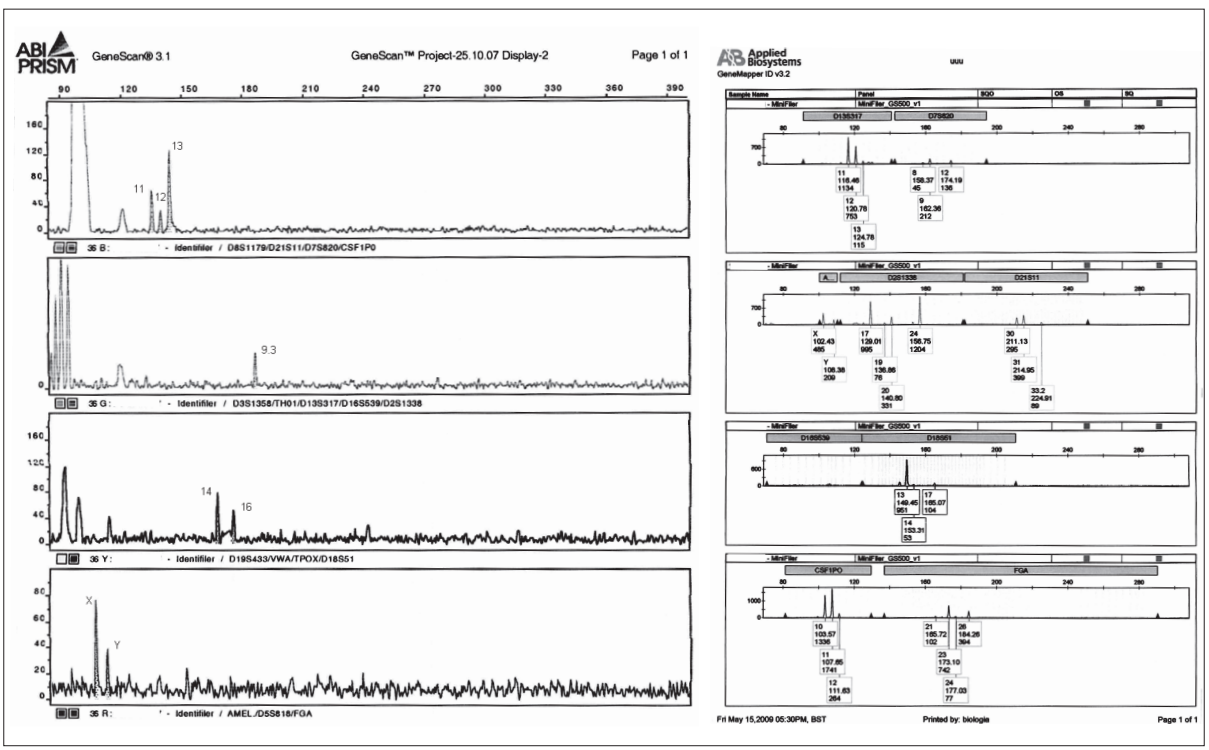

Figure 2 - Compromised sample (hand scrapings) analysed with Identifiler ${ }^{\mathrm{TM}}$ (a) and $\operatorname{MiniFiler}^{\mathrm{TM}}$ (b). 